\title{
Research on the Selection of Career Anchor Types for Graduates in Colleges and Universities
}

\author{
Liu Pingping \\ Beijing Wuzi University \\ Beijing, China
}

\begin{abstract}
The paper mainly studies the selection of career anchor types for graduates of colleges and universities. By Professor Schein's career anchor theory and inventory, selecting people who have graduated and have worked 1-3 years as research subjects, the paper tests career anchor inventory of these personnel and surveys career anchor types of these personnel.
\end{abstract}

Keywords-career anchor types; career anchor inventory; graduates in colleges and universities

\section{INTRODUCTION}

Undergraduate students in colleges and universities lack direct work experience and major practice, because of few opportunities in direct contact with the social and internship. Therefore, undergraduate students' ability to integrate their abilities, motivations and values is week. There is a certain lack of credibility and effectiveness of career development and planning of undergraduate students[1]. Selecting people who have graduated and have worked 1-3 years as research subjects of career anchor, in contrast to the undergraduate students' deficiency of career development and planning, the study even more is authentic, credible and effective. The study on the selection of career anchor types of graduates of colleges and universities can help colleges to further develop a clear understanding of career paths and career choices of undergraduate students, And it has important practical value for better planning undergraduate students' talent training model and training direction and it is an important reference value for further effective planning undergraduate students' training type.

\section{METHODOLOGY}

\section{A. The underlying theory}

Career anchor theory put forward by the famous professor Schein. It refers to a stable career orientation to achieve selfsatisfaction and compensation, after personnel entering into early work situation, determined by the practical work experience and consistent with motivation in introspection, values, competence[2]. Career anchor emphasize the interaction and integration of personal ability, motivation and values. Career anchor is divided into eight types by professor Schein: Technical/Functional Competence, General Managerial Competence, Autonomy/Independence, Security/Stability, Entrepreneurial Creativity, Pure Challenge,
Service/Dedication to a Cause, Lifestyle, and launched the career anchor inventory[3]. Career anchor theory is the theoretical basis of this study.

\section{B. The proposed empirical model}

Schein's career anchor inventory is one of the most widely used quantitative tools for measuring career anchor types[4]. It is a total of eight subscales, each subscale has five questions, is a 6-point scale. Testers are asked to set forth the truth of the subject case to answer[5]. Career anchor type with the highest score of the subscales is the career anchor type of testers.

\section{DATA}

\section{A. Data Description}

I conduct the survey for people graduated from one college and worked 1-3 years. The questionnaires are mainly issued by mail and e-mail. People filling in the questionnaires mainly relate to the majors in economics \& management, computer engineering, logistics engineering and English. The coverage of the major is broader.

500 questionnaires are issued, 479 questionnaires are collected back and 461 questionnaires are valid. Both the size of sample and representativeness of sample can meet the requirements of statistical analysis. Both the information reflected and conclusions are good statistical significance.

\section{B. Variable Description}

500 questionnaires are issued to people graduated from one college and worked 1-3 years and 461 valid questionnaires are collected back. Among them,149 questionnaires belong to people graduated from college and worked 1 year, 153 questionnaires belong to people graduated from college and worked 2 years, 159 questionnaires belong to people graduated from college and worked 3 years. In 461 valid questionnaires, 203 questionnaires belong to male staff and 258 questionnaires belong to female staff. In 461 valid questionnaires, 236 questionnaires belong to Economics \& Management Majors, 169 questionnaires belong to computer engineering \& logistics engineering majors and 56 questionnaires belong to English majors.

\section{EMPIRICAL RESULTS}

By professor Schein career anchor inventory, the effective 461 research subjects surveyed are classified by career anchor 
type. In the process of statistical results, we find the situation that the highest score of some research subjects of two or three career anchor types are the same. In this case, we have to be supplemented by telephone interviews to further confirm of the research subjects of the career anchor inventory. So that these research subjects can be distinguished by the only option type by the highest score.

TABLE I. CAREER ANCHOR TYPES DISTRIBUTION FOR PEOPLE GRADUATED FROM COLLEGE AND HAVE WORKED 1-3 YEAR

\begin{tabular}{|l|c|c|}
\hline \multirow{2}{*}{\multicolumn{1}{|c|}{ Career anchor types }} & \multicolumn{2}{c|}{ Empirical Results } \\
\cline { 2 - 3 } & Percent & Number \\
\hline Technical/Functional Competence & $6.59 \%$ & 30 \\
\hline General Managerial Competence & $1.10 \%$ & 5 \\
\hline Autonomy/Independence & $7.69 \%$ & 35 \\
\hline Security/Stability & $14.29 \%$ & 66 \\
\hline Entrepreneurial Creativity & $9.90 \%$ & 46 \\
\hline Pure Challenge & $6.59 \%$ & 30 \\
\hline Service/Dedication to a Cause & $24.18 \%$ & 112 \\
\hline Lifestyle & $29.67 \%$ & 137 \\
\hline & $100 \%$ & 461 \\
\hline
\end{tabular}

According to Table 1, career anchor type distribution for people graduated from college and worked 1-3 year as follows: the largest proportion of the career anchor types chose by people is Lifestyle. Secondly is Service/Dedication to a Cause. The third is Security/Stability. The smallest proportion of the career anchor types chose by people is General Managerial Competence. The last but one is Pure Challenge and Technical / Functional Competence. Autonomy/Independence is in the fourth place. And Entrepreneurial Creativity is in the fifth place.

Based on the investigation of career anchor type, the result can be analyzed that the work positions of undergraduate talents trained by this college are mostly the primary and middle positions and senior positions is small. Positions favored by these people are that content with relatively stable, challenging not strong, nor is it highly technical major, there is no strong idea of entrepreneurship. These positions are not high competitive jobs, indicating that they are low barriers to entry in the job market. These positions belong to the serious homogeneity positions in the job market. The highest proportion of career anchor type is Lifestyle. That means undergraduate students trained by this college pay more attention to balance work and family, indirectly shows the dedication and initiative of the work is not very strong. They hope to use their knowledge and skills to help others, indicating a strong sense of service.
TABLE II. CAREER ANCHOR TYPE DISTRIBUTION FOR PEOPLE GRADUATED FROM ECONOMICS \& MANAGEMENT MAJORS OF COLLEGE AND WORKED 1-3 YEAR

\begin{tabular}{|l|c|c|}
\hline \multirow{2}{*}{\multicolumn{1}{|c|}{ Career anchor types }} & Economics \& Management \\
\cline { 2 - 3 } Technical/Functional Competence & Percent & Number \\
\hline General Managerial Competence & $6.36 \%$ & 15 \\
\hline Autonomy/Independence & $1.27 \%$ & 3 \\
\hline Security/Stability & $8.05 \%$ & 19 \\
\hline Entrepreneurial Creativity & $14.83 \%$ & 35 \\
\hline Pure Challenge & $9.75 \%$ & 23 \\
\hline Service/Dedication to a Cause & $5.93 \%$ & 14 \\
\hline Lifestyle & $24.15 \%$ & 57 \\
\hline & $29.66 \%$ & 70 \\
\hline
\end{tabular}

TABLE III. CAREER ANCHOR TYPE DISTRIBUTION FOR PEOPLE GRADUATED FROM COMPUTER ENGINEERING AND LOGISTICS ENGINEERING MAJORS OF COLLEGE AND WORKED 1-3 YEAR

\begin{tabular}{|l|c|c|}
\hline \multirow{2}{*}{\multicolumn{1}{|c|}{ Career anchor types }} & \multicolumn{2}{c|}{$\begin{array}{c}\text { computer engineering and } \\
\text { logistics engineering }\end{array}$} \\
\cline { 2 - 3 } & Percent & Number \\
\hline Technical/Functional Competence & $7.69 \%$ & 13 \\
\hline General Managerial Competence & $1.18 \%$ & 2 \\
\hline Autonomy/Independence & $8.28 \%$ & 14 \\
\hline Security/Stability & $13.02 \%$ & 22 \\
\hline Entrepreneurial Creativity & $11.24 \%$ & 19 \\
\hline Pure Challenge & $8.28 \%$ & 14 \\
\hline Service/Dedication to a Cause & $23.08 \%$ & 39 \\
\hline Lifestyle & $27.22 \%$ & 46 \\
\hline & $100 \%$ & 169 \\
\hline
\end{tabular}

TABLE IV. CAREER ANCHOR TYPE DISTRIBUTION FOR PEOPLE GRADUATED FROM ENGLISH MAJOR OF COLLEGE AND WORKED 1-3 YEAR

\begin{tabular}{|l|c|c|}
\hline \multirow{2}{*}{\multicolumn{1}{|c}{ Career anchor types }} & \multicolumn{2}{c|}{ English } \\
\cline { 2 - 3 } & Percent & Number \\
\hline Technical/Functional Competence & $3.57 \%$ & 2 \\
\hline General Managerial Competence & $0 \%$ & 0 \\
\hline Autonomy/Independence & $3.57 \%$ & 2 \\
\hline Security/Stability & $16.07 \%$ & 9 \\
\hline Entrepreneurial Creativity & $7.14 \%$ & 2 \\
\hline Pure Challenge & $3.57 \%$ & 16 \\
\hline Service/Dedication to a Cause & $30.36 \%$ & 21 \\
\hline Lifestyle & $37.50 \%$ & 56 \\
\hline
\end{tabular}

According to Table 2-4, the selection of career anchor type for different majors in people graduated from college and 
worked 1-3 year has a great difference. The choice of General Managerial Competence is the highest proportion for people graduated from Economics and Management. That reflects the confidence in their specialty. The choice of Technical / Functional Competence, Autonomy / Independence, Pure Challenge career anchor type is the highest proportion for people graduated from Computer Engineering, Logistics Engineering. That explains the fact that people majoring in engineering graduated from college are full of confident that with what they have learned they can full play to their major advantage on the technical , independent and challenging position. At the same time, the desire of entrepreneurship with their major is also relatively strong. The choice of Security/Stability, Service/Dedication to a Cause, Lifestyle is the highest proportion for people graduated from English. People majoring in English are more. Career anchor types they preferred more emphasis on stable, service and safety. The desire of challenging career is relatively poor. While they quite balance work and family.

TABLE V. CAREER ANCHOR TYPES DISTRIBUTION FOR PEOPLE GRADUATED FROM COLLEGE AND WORKED ONE YEAR

\begin{tabular}{|l|c|c|}
\hline \multirow{2}{*}{\multicolumn{1}{|c|}{ Career anchor types }} & \multicolumn{2}{c|}{ Worked 1 Year } \\
\cline { 2 - 3 } & Percent & Number \\
\hline Technical/Functional Competence & $6.04 \%$ & 9 \\
\hline General Managerial Competence & $0.67 \%$ & 1 \\
\hline Autonomy/Independence & $8.72 \%$ & 13 \\
\hline Security/Stability & $12.08 \%$ & 18 \\
\hline Entrepreneurial Creativity & $12.08 \%$ & 18 \\
\hline Pure Challenge & $8.05 \%$ & 12 \\
\hline Service/Dedication to a Cause & $26.85 \%$ & 40 \\
\hline Lifestyle & $25.50 \%$ & 38 \\
\hline & $100 \%$ & 149 \\
\hline
\end{tabular}

TABLE VI. CAREER ANCHOR TYPES DISTRIBUTION FOR PEOPLE GRADUATED FROM COLLEGE AND WORKED TWO YEARS

\begin{tabular}{|l|c|c|}
\hline \multirow{2}{*}{\multicolumn{1}{|c|}{ Career anchor types }} & \multicolumn{2}{c|}{ Worked 2 Years } \\
\cline { 2 - 3 } & Percent & Number \\
\hline Technical/Functional Competence & $6.54 \%$ & 10 \\
\hline General Managerial Competence & $1.31 \%$ & 2 \\
\hline Autonomy/Independence & $7.84 \%$ & 12 \\
\hline Security/Stability & $15.03 \%$ & 23 \\
\hline Entrepreneurial Creativity & $9.80 \%$ & 15 \\
\hline Pure Challenge & $6.54 \%$ & 10 \\
\hline Service/Dedication to a Cause & $26.14 \%$ & 40 \\
\hline Lifestyle & $26.80 \%$ & 41 \\
\hline & $100 \%$ & 153 \\
\hline
\end{tabular}

TABLE VII. CAREER ANCHOR TYPES DISTRIBUTION FOR PEOPLE GRADUATED FROM COLLEGE AND WORKED THREE YEARS

\begin{tabular}{|l|c|c|}
\hline \multirow{2}{*}{\multicolumn{1}{|c|}{ Career anchor types }} & \multicolumn{2}{c|}{ Worked 3 Years } \\
\cline { 2 - 3 } & Percent & Number \\
\hline Technical/Functional Competence & $6.92 \%$ & 11 \\
\hline General Managerial Competence & $1.26 \%$ & 2 \\
\hline Autonomy/Independence & $6.29 \%$ & 10 \\
\hline Security/Stability & $15.72 \%$ & 25 \\
\hline Entrepreneurial Creativity & $8.18 \%$ & 13 \\
\hline Pure Challenge & $5.03 \%$ & 8 \\
\hline Service/Dedication to a Cause & $20.13 \%$ & 32 \\
\hline Lifestyle & $36.48 \%$ & 58 \\
\hline & $100 \%$ & 159 \\
\hline
\end{tabular}

According to Table 5-7, we classify research objects with respect to graduating time which is 1 year, 2 years, 3 years of graduation. So we can analyze their career anchor types. With the results, the proportion of General Managerial Competence in these three years is from low to high. With the increase of the passage of time and work experience, some people gradually got into management positions. The proportion of Autonomy/Independence in these three years from high to low, indicating that with increasing time of graduation, people gradually adapt to the change from students to staff and more responsive to working life. The proportion of Entrepreneurial Creativity in these three years is from high to low. That means the hearts of entrepreneurship dreams become in reality more real and cruel, that is the entrepreneurial process may be a little setback, thus, changes their career paths. The proportion of Pure Challenge in these three years is from high to low. Causes may be the same as Entrepreneurial Creativity type. The proportion of Service/Dedication to a Cause in these three years is from high to low, indicating that the love and dedication to work has decreased with the increase of time. The proportion of Security/Stability and Lifestyle in these three years is from low to high, indicating that with age increasing, people pay more attention to the work of stability and security, as well as the balance between work and family.

The above is an empirical study on career anchor based on one college in China. Because this project is currently being studied, some conclusions may not quite perfect, I hope you can understand. The above findings can be introduced to colleges and universities to help them in the process of talents training model and talents training type. And we hope the findings can help colleges more efficient and targeted in the talents training.

Research perspective can also be expanded, for example, select key universities, famous universities to study career anchor types and analyze talents advantage. We can also compare career anchor types of undergraduate students for the same major in different universities to trained people to clear their own major training of university strengths and expertise. These are the future we need further investigation. 


\section{CONCLUSIONS}

Quantitative study on career anchor is not much in China. Research subjects in the quantitative study are undergraduate students in colleges and universities were less. Research subjects of study are people graduated from colleges and universities and worked 1-3 years are not found. The paper selects people graduated from colleges and universities and worked 1-3 years as research subject. These subjects meet the research field of Professor Schein's career inventory.

Both undergraduate students' talent training mode, training type, training direction for colleges and universities, and advance understanding of fitting between occupations and major to be more targeted employment options are the most valuable parts of this study. Previous studies on career anchor of undergraduate students in colleges and universities are major foothold on employment, but did not rise to the height of talent training. Therefore, this is an important value of the present study.

\section{REFERENCES}

[1] MA Ke-yi. "An Analysis of the Relationship between Cognitive Resources and Career Anchor in Work Settings.” Journal of Zhejiang University(Humanities and Social Sciences). Vol.30 , No .6, pp. 21-25, Dec .2000.

[2] YAO Li-xia. "Relationship between A-Type Personality and Career Anchors among Post-80s College Graduate Employees.” Chinese Journal of Applied Psychology. Vol.20, No. 3, pp.272-279. 2014.

[3] Liu Linhui , Liu Jiajia. "Current Situation and Relationship Study on Career Anchor and Career Maturity of College Students.” Social Psychological Science Vol.26 No.11-12 ,pp. 191-194. 2009.

[4] ZHANG Dong-mei, XU Ling. "Meterage of career anchor and exertion for college student's career planning.” Journal of Xi' an Polytechnic University. Vol.23, No.3,pp. 145-148, 2009.

[5] Xu Huijuan. "Career Anchor and Its Impacts on Managers ' Career Lifecycle.” Journal of WUT( Information \& management engineering). Vol. 28 No. 8,pp. 136-141, 2008. 